\title{
Trade and Territorial Conflict in Latin America: International Borders as Institutions
}

\section{Citation}

Simmons, Beth. 2006. Trade and Territorial Conflict in Latin America: International Borders as Institutions. In Territoriality and Conflict in an Era of Globalization, ed. Miles Kahler and Barbara F. Walter, 251-287. Cambridge: Cambridge Univ. Press.

\section{Published Version}

10.1017/cbo9780511491450.010

\section{Permanent link}

http://nrs.harvard.edu/urn-3:HUL.InstRepos:32186261

\section{Terms of Use}

This article was downloaded from Harvard University's DASH repository, and is made available under the terms and conditions applicable to Other Posted Material, as set forth at http:// nrs.harvard.edu/urn-3:HUL.InstRepos:dash.current.terms-of-use\#LAA

\section{Share Your Story}

The Harvard community has made this article openly available.

Please share how this access benefits you. Submit a story.

\section{Accessibility}


31 See the oral argument in Reid I, in Landmark Briefs. The sixty-three figure comes from the US government's oral argument in Reid II.

32 Brief in Reid I, 98.

33 Personal communication, Eileen Scully, May 2004.

34 Missionaries were the other large category.

35 Oral argument in Reid II in Landmark Briefs of the Supreme Court, 824.

36 Reid II (354 US 1 (1957)), 72.

37 Ibid., 12.

38 Indeed, the Bush administration continues to argue that the detainees held in Guantanamo and other locations abroad lack any constitutional rights whatsoever. The decision in Rasul rested solely on statutory grounds.

39 On the extent of deference, see Franck 1992.

\section{Trade and territorial conflict in Latin America: international borders as institutions}

\author{
Beth A. Simmons
}

More than three decades ago, Richard Cooper stated that "the trend toward economic interdependence between countries will require substantial changes in their approach to foreign policy in the next decade or so" $(1972,159)$. A wide range of studies has since been premised on the proposition that interdependence has significantly raised the costs to governments and the economies they govern of taking unilateral action. One solution to problems of coordination and collaboration among states has been to develop international institutions that reduce transactions costs and uncertainty, allowing states to enjoy greater mutual gains than would have been possible in the absence of such institutions.

The institutional paradigm has informed a broad range of studies in international political economy (Simmons and Martin 2002). The same cannot be said of international conflict studies. Scholars looking at interstate disputes have typically bypassed institutional theory, focusing instead on the basic constellations of state power. The irony is that war and peace often revolve around the most ubiquitous international institution of the modern age: sovereign authority over delimited territorial space.

This chapter argues for a reconceptualization of international borders as they have come to be understood in the international relations literature. One branch of that literature has emphasized the extent to which disputes over territory, more than any other issue, have spurred interstate rivalry, military confrontation, and all-out war. Borders as territorial divisions are then analyzed as zero-sum manifestations of state competition for power, prestige, lebensraum, or an imagined historical identity. Hein Goemans' contribution to this volume has a creative take on the security dimensions of territorial borders, viewing them as focal points for collective defense, group cohesion, and, ultimately, survival.

Yet the globalization literature continually reminds us that we live in a world in which territory matters less, and human capital matters more, 
to national power. It also entreats us to believe that national boundaries matter less now than they ever have in the past. Markets override national boundaries, causing some commentators to suggest that our world is increasingly "borderless" (Ohmae 1990).

Neither of these conceptions is useful for understanding the role of international boundaries in a world of potentially highly interdependent nation-states. In such a world, international borders are more important than ever, but they are increasingly inappropriate objects of interstate competition. The best way to understand this irony is to theorize about international borders as international political-economic institutions that produce not only divisible benefits, but mutual benefits as well. As I will show, thinking about borders in this fashion is not only plausible; it also resolves a number of issues that from the traditional realist and the globalization perspectives are puzzling. ${ }^{1}$

This study proceeds in three sections. The first section sets out the argument that international borders that are accepted by adjacent states as legitimate should be thought of as international institutions that enhance certainty, reduce transactions costs, and provide mutual gains that are eroded or lost if the legitimacy of the border is in dispute. I concede that, from an economic point of view, a world of separate jurisdictions is less efficient than one of distinct nation-states. But given a state system, settled territorial boundaries allow governments to realize important economic and political benefits that are very difficult to achieve in the absence of a well-accepted international border agreement. I will demonstrate this in a very concrete fashion by showing that there are substantial opportunity costs to disputing the accuracy or legitimacy of a particular territorial division.

The second and third sections develop the methodology and demonstrate this claim empirically. Using a gravity model of trade, and controlling for a broad range of likely alternative explanations, I show that the mere fact of disputing a border has a significant negative impact on contiguous countries' bilateral trade. This is true even when we control for the effects of the actual threat or use of force. In short, I show that there is a high opportunity cost to disputing an international boundary. The argument is not that globalization and post-industrial technological advances have made territory per se less important, an idea Erik Gartzke effectively refutes in his contribution to this volume. Rather, it is that borders as institutions for organizing understandings about jurisdiction over territory are increasingly important as the potential for economic interdependence increases. I conclude in section four that settled borders are an important international institutional arrangement that, as long as we live in a world of nation-states, is helpful to further economic integration. The consequences for our understanding of international conflict and cooperation in this area are profound.

\section{Borders as institutions}

Geographers usually define international boundaries as spatial manifestations of political control displayed in the landscape (Rumley and Minghi 1991). As such, international boundaries separate areas subject to different political control or sovereignty. They represent the physical line of contact between states, and afford opportunities for both cooperation and discord (Prescott 1987, 5).

It is the latter feature of international boundaries that has received so much attention in the international relations literature. Borders place physical limits on the exercise of state authority, as well as providing the physical space available for the provision of national security. For these reasons, they are a primary concern of scholars in the realist tradition who view power and the search for security as the central features of international relations. Hans Morgenthau, who was remarkably eclectic in this regard, placed geography and natural resources - elements closely associated with territory - right at the top of the list of elements of national power (Morgenthau 1985, 127-36). Moreover, he emphasized territorial reallocation as a central way to preserve the balance of power, a process he characterized as achievable by "diminishing the weight of the heavier scale or by increasing the weight of the lighter one" (Morgenthau 1985). Yet one ought not to portray his approach as unduly mechanistic. Morgenthau was also willing to consider national character, national morale, and the problem of popular support as important determinants of national power. ${ }^{2}$ Each of these, of course, can be closely linked with the prospects of territorial loss or accretion.

Realist thinking overlapped with conceptions of the state and territoriality developed by early twentieth-century scholars of geopolitics (Mackinder 1904). Robert Gilpin's claim that "throughout history" states have had as a principal objective "the conquest of territory in order to advance economic, security, and other interests" (Gilpin 1981, 23) is not radically different from the claims of classical nineteenth-century scholars, whose theories treated states as "competitive territorial entities vying with one another for control over parts of the earth's surface" (Murphy 2001).

For those who draw inspiration from realist theory, an international boundary is typically conceived of in zero-sum terms. Gary Goertz and Paul Diehl provide the clearest contemporary expression of this general assumption: 
Because a territorial dispute is primarily zero-sum (usually only one entity can control a piece of land) it may appear surprising that the vast majority of al territorial changes over the last 165 years have been completed peacefully.

Goertz and Diehl 1992, 51)

The assumption has informed a good deal of research that shows disputes over territory are much more prone to degenerate into violent interstate conflict than are disputes over other issues (Brecher 1993; Gochman and Leng 1983; Hensel 1999; Senese 1996). Disputes over territory have been linked to ongoing violent rivalries between states, as well as to the frequency and intensity of war (Goertz and Diehl 1992; Holsti 1991; Huth 1996; Mandell 1980; Vasquez 1993; Vasquez 1995). Studies that focus on the resolution of territorial disputes almost always focus on external security variables, though in light of the literature on the "democratic peace" more attention has been given to domestic regime type and international norms (Huth 1996; Kacowicz 1994).

The realist approach to territorial issues has not quite figured out what to do with a few stubborn facts. The first is highlighted in the quote by Goertz and Diehl above. If control over territory is truly zero-sum and so closely connected to issues of national security, why has territory so often been transferred peacefully? Immediately one thinks of imposed solutions where resistance may have been deterred, but there are other apparent anomalies from a realist perspective. Paul Huth cites evidence that in all of the years since World War II, less than one-third of all international borders have been disputed (Huth 1996, 8). The best empirical analysts merely flag these as "null cases" for purposes of statistical controls, but they are of serious theoretical import. Why are so many borders accepted as legitimate and uncontested? Even in the Middle East, usually perceived as a hotbed of territorial contention, formal mutually accepted treaties exist for 80 percent of the region's land boundaries (Blake 1992). Realists do not have a clear answer for why so much of the world should have been in apparent equilibrium for the past half-century. Institutionalism on the other hand provides insights, which we discuss below.

Moreover, it is difficult to articulate (and to my knowledge, no one has attempted) a realist account for the decline in the use of force in cases of territorial disputes. Yet there is an emerging scholarly consensus that disputes are less and less often resolved through violence. One revealing statistic is that territorial change as a result of violence dropped from 33 percent before World War II to 16 percent afterwards (Goertz and Diehl 1992, 52). Edward Morse attributed this development to the forces of modernization, including the rise of economic interdependence (Morse
1976). Mark Zacher has proposed a more normative explanation, arguing that growing acceptance of an "anti-territorial revisionism norm" discourages the use of violence in border disputes (Zacher 2001).

While realists are working out empirical explanations of the hows and whys of boundary disputation and territorial transfer, the globalists are telling us that none of this should matter. Though not all go as far as Ken'ichi Ohmae, who asserts that the world is now "borderless" (Ohmae 1990; Ohmae 1995), it is rather commonly accepted that borders are declining in economic significance (Herz 1957; O'Brien 1992) as well as social-cultural significance (Agnew and Duncan 1989; Appadurai 1996). Richard Rosecrance has long argued that trade increasingly trumps territory as a source of national power (Rosecrance 1986; Rosecrance 1996). John Stopford and Susan Strange have argued extensively that competition for world markets, for example, has replaced competition for territory, or for control over the natural resources of territory, as the "name of the game" between states (Stopford and Strange 1991; Strange 1996). Geographers as well as political scientists in the 1990s have argued that the control of networks of finance, information, and transportation are much more important than control over territory per se (Agnew and Knox 1994; Kobrin 1997; Luke 1991; Murphy 1999; Ruggie 1993).

The evidence for these claims is in most cases episodic, but where it has been systematic, it has not been especially supportive of the irrelevance of international borders. Although internationalization in today's "global era" is no doubt real and important, national boundaries continue to have significant influences on international economic relations. Globalists are at a loss to explain why international investment is not more globalized than it is: why is there such a "home bias" when it comes to investing (Goldstein and Mussa 1993; Sobel 1994)? John McCallum's study of bilateral trade between the United States and Canada was the first to show empirically that a "borderless" North America does not yet exist: as of 1990, trade between Canadian provinces was on average almost 22 times trade between a similar Canadian province and a US state, all other factors being held equal (McCallum $1995,617)$. This study served as the foundation for a more complete and comprehensive study by John Helliwell, who not only confirmed McCallum's findings, but also found that even after the Free Trade Agreement (FTA) of 1990, US-Canada border effects were still in the tenfold range (Helliwell 1998, 21). Furthermore, Helliwell extended the analysis to trade between all countries in the 1986-96 period, showing that border effects were an international phenomenon, and particularly acute for developing countries (Helliwell 1998, 59). Departing from 
McCallum and Helliwell's trade-centered analyses, Charles Engel and John Rogers confirmed the importance of borders using the "law of one price." They showed that even after holding all other factors equal, price divergences between cities in different countries are much greater than between cities in the same country (Engel and Rogers 1996). Borders, they claim, are indeed still quite "wide."

What is needed is a way to think about international boundaries that is neither prisoner to realism's zero-sum approach to traditional concerns of state security, nor falls prey to claims that borders do not matter. It is instructive to return to the description by Prescott (a geographer) of an international boundary and to notice how much it has in common with the conditions which international relations scholars have associated with those giving rise to "interesting" issues with respect to cooperation (Keohane 1984). International boundaries involve "mixed motive games" which Schelling characterized as having elements of "mutual dependence, and conflict, of partnership and competition" (Schelling $1980,89)$. Realists have spelled out quite well the competitive elements in boundary determination and acceptance: territory may have symbolic, political, historical, or other kinds of significance that make it difficult for states to give it up. On the other hand - and this is rarely emphasized in the literature on territory and boundaries - well-accepted international border arrangements provide mutual benefits for states that may be very difficult for either to realize through unilateral policies.

Governments may want to maximize their territorial authority, but like players in a game of battle of the sexes they may place a good deal of importance on capturing the value associated with agreeing on the line. Governments may in some cases be relatively indifferent to where the exact line is drawn (at least over the range of territory that is being negotiated), and may place far more value on settlement itself. I argue this is because an institutionalized border arrangement provides benefits that each country can only enjoy if it cooperates with its neighbor in resolving the border dispute. Primarily, these benefits flow from the certainty and the reduction in transactions costs associated with a normalization of relations regarding the border.

Just what are some of these benefits that require mutual acceptance of the border? In this chapter I focus on the economic benefits. All of the economic literature suggests that trade is highly sensitive to the risk and transactions costs involved among even the friendliest of trade partners (the studies cited above found significant effects to the border between countries as friendly as the United States and Canada). Now insert contention over the extent of territorial authority. There are good theoretical reasons to believe that such a dispute would inject marked uncertainty and risk into developing cross-border trade links. Most obviously, the dispute could become active, and most studies have shown that war reduces bilateral trade volumes (Anderton et al. 1999; Anderton and Carter 2001). ${ }^{3}$ More subtly, the disputing governments may be more likely to interfere with trade at the border (customs hassles) or to develop explicit policies to reduce their mutual dependence out of mutual suspicion of one another's motives and intentions stemming from the territorial dispute (Hirschman 1945). In some cases, the border might simply be closed for security reasons. In any case, a heavy military or police presence of a hostile state around the border itself is unlikely to be very inviting to traders.

But the broader reasons for stagnant trade will have to do with the general uncertainty surrounding property rights (broadly conceived) when two countries' governments dispute territorial jurisdiction. Should an investment be made in developing relationships with suppliers or marketing to consumers in a country with which relations are so uncertain? Subjection to hostile propaganda campaigns is another potential problem. In short, traders face costs and risks of developing business links in countries with which their government has a dispute. ${ }^{4}$ The territorial dispute over the Kurile Islands, for example, has caused economic relations between Japan and Russia to stagnate, even while those between Russia and Korea have continued to expand (Akaha 1996; Linge 1995; Meyer 1998). ${ }^{5}$

Historically, the link between settling an outstanding territorial claim and improving bilateral trade has often been manifest in the nearly simultaneous conclusion of territorial agreements and treaties of "friendship, commerce, and navigation." For example, Argentina and Bolivia addressed border issues in a Friendship, Commerce, and Navigation Treaty in 1868; Chile and Argentina settled the Beagle Channel dispute and signed a friendship and commerce treaty in 1984; Brazil and Peru signed a series of boundary treaties that also addressed commerce and navigation (1841, 1851, 1909) (Ireland 1938; Ireland 1941). Governments have historically been willing to facilitate international economic relations once disputes over territory have been settled.

International investors may be even more wary than traders of crossborder contracts involving jurisdictional disputes over the border. In the case of the Saudi-Yemeni border dispute (settled by treaty, 12 June 2000 ), the expectation that the region was well-endowed with hydrocarbons drove attempts to negotiate a boundary settlement (Schofield 1997). But even if we consider the broader decision to invest away from the border, investors are likely to run risks of a sovereign-induced nature if they sink assets in countries that have a fundamentally hostile posture 
to their home country. Finally, despite the inherent attractions of some border regions (Timothy 1995), tourists can hardly be expected to flock to border regions that may be heavily armed, or that lack basic infrastructural investment owing to the dispute over the border. Though we rarely consider this impact, tourism is increasingly significant to the economies of many countries. These are opportunities forgone for the lack of clearly accepted understandings about the international border.

There is another reason why unsettled borders are potentially costly to governments: they may stand in the way of regional economic integration. The prospect of Turkey or Cyprus joining the European Union, for example, has run up against the territorial claims of the former over portions of the latter, as well as other disputes involving Greece in the Aegean Sea (Joseph 1996; Theophylactou 1995). Leaders in both Peru and Ecuador viewed regional economic integration primarily emanating from Mercosur as an incentive to settle the border. The alternative was to risk getting left behind as the rest of Latin America developed stronger trade relations. Exclusion from regional arrangements in some cases is another opportunity cost of territorial disputes.

If we view settled international boundaries as valuable international institutions that provide joint benefits to adjacent governments, then we can understand some findings that from a realist perspective appear quite anomalous. Goertz and Diehl, for example, expect that "the greater the intrinsic value of the territory involved, the more likely military conflict is to be a part of the transfer" (Goertz and Diehl 1992, 88). Yet Paul Huth found that "when economic issues are predominantly at stake then compromise settlements are quite likely" (Huth 1996, 153). How can a realist, especially one concerned with relative gains (Grieco 1988; Mearsheimer 1994-95) explain such an outcome? It is easily explicable in institutionalist terms: without a settlement, these would have been economic gains largely forgone for lack of investment - the result of uncertainty and transactions costs for private actors associated with governmental territorial disputing. (It is interesting to note, however, that Huth explains the propensity to settle where economic issues are at stake as flowing from the ease of dividing, rather than the institutional potential for generating, economic benefits.) ${ }^{6}$

There are good reasons for accepting this paradigm shift with respect to borders. The traditional geopolitical concept of security as defense of territory and containing or neutralizing threats to a nation's sovereignty has come to be regarded as narrow and even self-defeating. ${ }^{7}$ Governments are often willing to expand the parameters of security to include inputs of economic development, social reconstruction, and empowerment of human rights. ${ }^{8}$ In the case of the Peru-Ecuador conflict, governments were increasingly aware of the opportunity costs they pay in terms of domestic social development and lost international trade and investment (Simmons 1999). In that case (finally resolved in 1998) Peruvian and Ecuadorian leaders were motivated to build agreements on joint development into the border agreement, and then marketed the package to the broader community of international investors (Simmons 2005).

To summarize: international border arrangements can be fruitfully analyzed in institutionalist terms. Settled borders signal to private economic agents that military conflict is less likely, that economic development is a higher value than territorial acquisition, that hostile harassment at the border is much less likely, and that property rights will not be subject to jurisdictional controversies. In short, settling territorial disputes is a costly signal that a state has made the conversion from a territorial state to a trading state. In the next section, some plausibility is provided for these arguments by demonstrating just how costly territorial disputes can be. There is no denying that such disputes can be costly in terms of human life, military expenditures, and lost trade when these conflicts become hot. But what I seek to show is that, even when controlling for the threat or use of force and other sources of bilateral tensions, merely disputing the border is a costly drag on bilateral trade. ${ }^{9}$ These costs are documented using a gravity model, to which is added the presence of a territorial dispute. The results suggest that institutional arrangements that reduce uncertainty and transactions costs go a long way toward supporting the conditions under which economic integration may flourish.

\section{Data and methodology}

Establishing a baseline for trade: border effects using a gravity model of bilateral trade

The strategy of this section is to isolate the effects of a disputed border on the bilateral trade between two countries. ${ }^{10}$ The central hypothesis is that disputed borders involve tremendous economic opportunity costs, which are conceptualized for purposes of empirical testing as bilateral trade forgone. The problem is how to estimate the size of this "lost opportunity," controlling for other plausible determinants of trade.

I employ a gravity model of trade, which has been widely used to examine bilateral trade flows since it was pioneered in the $1960 \mathrm{~s}$ (Linnemann 1966; Poyhonen 1963; Tinbergen 1962). The basic gravity model is a very simple empirical model that explains bilateral trade 
between countries as proportional to their "mass" (usually captured by gross domestic product) and inversely proportional to the distance between countries. This simple baseline model has a remarkably consistent history of success as an empirical tool. The response of bilateral trade to income and distance regularly produces large, correctly signed, and statistically significant coefficients (Davis et al. 1997; Frankel et al. 1997; Helpman 1984; Leamer and Levinsohn 1995; Linnemann 1966).

Gravity models of trade now have a clear and convincing link to international trade theory (J. E. Anderson 1979; Oguledo and MacPhee 1996). Constant-returns Hecksher-Ohlin trade models can generate the basic gravity equation, in the presence of large factor endowment differences between countries that support trade specialization and interindustry trade (Deardorff 1998; Evenett and Keller 1998; Leamer 1974). This theory has been especially useful for analyzing the volume of north-south trade (Marcusen and Wigle 1990). On the other hand, increasing returns models can also generate the specialization required for gravity models to make conceptual sense, but are more likely to apply to trade within regions and to generate high proportions of intra-industry trade (Bergstrand 1989; Helpman 1984; Helpman 1987). Since the relationships specified in the gravity equation are basically consistent with more than one theoretical tradition, scholars have emphasized that it is less useful for discriminating between theories of trade than for making empirical predictions about the volume of trade itself (Deardorff 1998).

The empirical robustness and theoretical foundations that have been drawn make the gravity model highly useful for exploring the impact of a broad range of factors on a baseline model of trade. For example, by including a variable for regional trade institutions, a number of scholars have used this approach to study the extent to which regional trade arrangements are trade-creating or trade-diverting (Bayoumi and Eichengreen 1995; Frankel and Wei 1993; Hamilton and Winters 1992; Polak 1996). Andrew Rose uses a gravity model as a baseline to measure the impact of currency union on international trade (Rose 1999). Rebecca Summary examined the effects of political rights on arms trade using this approach (Summary 1989). Brian Pollins includes membership in free trade agreements such as NAFTA, LAFTA, and the EU, as well as a "conflict and cooperation index," in order to study the relationship between foreign policy and trade (Pollins 1989). Gravity models have been used to explain patterns of trade in sectors from wheat to apparel to mobile communication flows (Christerson 1994; Koo and Karemera 1991; Matthes 1994). It is employed here to ask: how much does a border dispute detract from expected bilateral trade volumes?
Trade and territorial conflict

Gravity models of bilateral trade typically take the following form

$$
\mathrm{T}_{a b}=f\left(\mathbf{Y}_{a b}, \mathrm{D}_{a b}, \mathbf{R}_{a b}\right)
$$

$\mathbf{T}$ represents the trade flow between countries; $a$ and $b ; \mathbf{Y}$ represents the economic size of the two countries; $\mathbf{D}$ represents the physical distance from country $a$ to $b$; and finally, $\mathbf{R}$ represents other factors that may resist or encourage trade between $a$ and $b$. Because we are interested in the effects of a settled, mutually accepted border on bilateral trade flows, we use the following specification of the gravity model

$\log \left(T_{a b}\right)=\beta_{0}+\beta_{1} \log \left(Y_{a}+Y_{b}\right)+\beta_{2} \log \left(D_{a b}\right)+\beta_{3}(B D)+\beta_{4}($ controls $)+\epsilon$

The dependent variable $\log \left(\boldsymbol{T}_{a b}\right)$ represents the logged total flow of dyadic trade expressed in millions of US dollars. ${ }^{11} \log \left(\boldsymbol{Y}_{a}+\boldsymbol{Y}_{b}\right)$ represents the combined economic size of the two trading nations, measured as the logged gross domestic product. The expected coefficient is positive. $\log \left(\boldsymbol{D}_{a b}\right)$ represents distance between capitals of the country dyad, expressed in logged kilometers. The expected coefficient is negative, as greater distance represents greater transportation costs that should add "economic distance" and thus decrease trade volume. $\boldsymbol{B D}$ represents the existence of a border dispute, coded as 1 if there is a dispute between the two countries, otherwise 0 . The expected coefficient is negative; our central expectation is that disputes reduce bilateral trade.

\section{The primary explanatory variable: defining territorial disputes}

A crucial question is how one identifies a territorial dispute. Conceptually, we are interested in overlapping territorial claims that can be expected to instill uncertainty regarding jurisdictional authority, even in the absence of the overt use of military force. Paul Huth has developed a useful set of criteria for selecting cases that fit our concern. He coded territorial disputes as cases of governments' disagreement over the location of a border (whether or not a treaty has attempted to spell this out); when one country occupies the national territory of another and refuses to relinquish control or withdraw; when one government does not recognize the sovereignty of another over some portion of territory within the border of that country; or when a government does not recognize the independence and sovereignty of another country (or colonial territory), and seeks to annex some or all of its territory (Huth 1996, 19-23).

In Huth's study, disputes are considered "resolved" when these conditions are reversed. ${ }^{12}$ I favor Huth's rather stringent definition of resolution - involving governments' formal acknowledgment of the legitimacy of a particular border arrangement - because the argument turns 
precisely on institutions' role in reducing transactions costs and uncertainty. Publicly articulated arrangements of a formal nature are more likely to produce the confidence in resolution upon which our theory turns. ${ }^{13}$ I therefore use Huth's list of cases, updating them where necessary (see Appendix 1; disputing dyads are also listed in Table 10.2, discussed below).

\section{Controls}

I also include a set of control variables that could influence bilateral trade levels. First, it is important to control for policies that independently could improve bilateral trade. Certainly it is possible that each country's general trade posture (its commitment to protection to enhance selfsufficiency, its overall development strategy) could be a central determinant of bilateral trade levels as well. I include total exports plus imports to and from the rest of the world as a proportion of GDP for each country (multiplied and logged) to control for general trade posture. The expectation is that bilateral trade is partially a function of two countries' general trade policy. The more open generally, the more positive the effect on bilateral trade. I also control for the effects of common membership in preferential trade arrangements. Independent of whatever effects one might want to ascribe to a territorial dispute, we would expect preferential trade agreements to have a positive effect on bilateral trade among members. I code each country-pair as 1 when both parties are members of the same agreement or arrangement. I control for time as well. The expectation is that all trade is increasing over time, and thus that we should see a strong positive correlation of bilateral trade with the passage of time.

A second cluster of controls is designed to reduce the possibility that territorial disputes and trade are both driven by deeper bilateral tensions. If bad underlying relations both drive border disputes and deter trade, the link between trade and border institutions could be spurious. Since the argument revolves around settled boundaries per se, non-territorial sources of conflict must be taken into account.

As a first cut, I distinguish my argument about stable territorial institutions from arguments about the consequences of war or the threat of military force for commercial relations. Empirical studies suggest that war between countries reduces their bilateral trade. Admittedly, this is likely to be true, but here it is argued that the prolonged uncertainty of an ongoing dispute over territory is a more pervasive detriment to trade than actual cases of the use of force. Countries need not actually brandish their military might or engage in armed conflict to incur the opportunity costs of disputing their borders. ${ }^{14}$ We are more interested in negative externalities associated with unsettled borders for cross-border trade, though we would expect the actual use of force to reduce trade as well.

Another way to isolate border disputes is to distinguish them from other kinds of bilaterally disruptive political claims. Surely one of the most significant sources of bilateral conflict flows from challenges to the legitimacy of another government's rule. "Regime claims" involve instances in which one government has publicly called for the removal of another government from office. Disputes over the legitimacy of governance might fan the flames of a territorial dispute and simultaneously reduce the willingness to permit or facilitate bilateral trade. We should expect a strong negative effect on trade when such challenges have been issued.

At a more subtle yet possibly more pervasive level, one might suspect that both bilateral trade patterns and territorial disputing are jointly influenced (and hence only spuriously related) by a more basic underlying disagreement or divergence in policies, interests, or outlook between two governments. Far short of serious disputes that would elicit military threats, governments may have significant policy differences that serve to throw sand in a range of harmonious bilateral relations. If underlying political conflict explains both meager trade and hostile border policies, the empirical case for an institutional theory of borders is weakened. Measuring underlying comity is difficult, but one approach is to control for similarity of positions on foreign policy issues. I experiment by controlling for the extent of similarity within each country-pair on votes on the United Nations General Assembly. While hardly a perfect measure, on average (and despite occasional strategic voting) it captures the underlying degree of "affinity" between country-pairs on a range of issues in world politics. ${ }^{15}$ Conversely, a low or falling index should indicate the potential for underlying tensions within a countrydyad. Additionally, I try to control for a propensity for underlying conflict by controlling for those dyads with at least one nationalistic government. ${ }^{16}$ If the link between territorial disputes and lower than expected bilateral trade is spurious, the common cause could be nationalism.

Since so much of the literature suggests its importance in other contexts, I control for the possibility that certain regime types are simply more likely to enjoy cordial bilateral relations than are others. More democratic countries may simply tend to be more liberal economically and may very well have more intense bilateral trading relationships. I use a dichotomous indicator for a democratic pair - coded 1 when both countries score above 5 for democratic governance on the Polity scale 
of -10 (low) to 10 (high). Nationalist governments might be more willing to exploit and even manipulate public sentiments to revive dormant disputes as well as to protect domestic producers from international trade competition. Controlling for these regime characteristics should therefore reduce the possibility that we are incorrectly attributing a causal impact to settled international borders.

A third set of variables controls for the possibility that the uncertainty that I argue follows from unsettled boundaries is actually domestic in origin. After all, a host of internal conditions could in theory discourage economic actors from making the investments necessary for profitable bilateral trade. My argument rests on the uncertainty generated by the unsettled border itself. I therefore control for two sources of domestic uncertainty: domestic armed violence and domestic political instability. Their inclusion raises the probability that a theory of international borders as uncertainty-reducing institutions has some empirical traction.

Since, as described below, a fixed-effects model is used, over-time variance in these explanatory variables is important. Appendix 2 indicates how the incidence of military disputes, the regime type of each pair, and the level of overall trade openness have varied for each country-pair over time (see Appendix 1 for all data measures and sources).

\section{Case selection and estimation methods}

These ideas are tested using territorial disputes from Latin America between 1964 and 2000. This region of nearly half a billion people affords a good opportunity to assess claims about the importance of settled borders for trade. Most importantly, it is a region in which the boundary conditions of our theory are likely to hold. That is, evidence suggests that for the most part governments in this region are likely to value trade, as past experiments with import substitution have been set aside and conscious efforts over the last two decades to develop regional trade through such institutions as Mercosur, the Andean Pact, and the Central American Common Market have accelerated. Figure 10.1 illustrates the growth in share of GDP in Latin American that is traded intra-regionally and with the rest of the world.

Focusing on Latin America also holds some variables constant: language, culture, and highly charged ethnic conflicts are not likely to be at play in border and trade relations in this region. This region is also appropriate because of its long history of political independence. Unlike areas which have more recently been under foreign administration, trade is less likely in Latin America to be distorted by colonialism. More

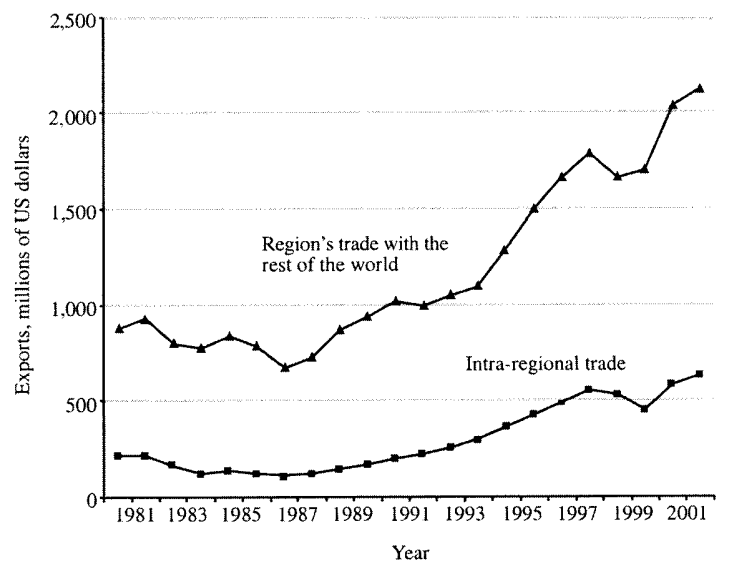

Figure 10.1. Latin American and Caribbean trade with the rest of the world.

generally, there are good reasons to believe that regions are highly heterogeneous and that to pool them at this point in our research would be premature. While border disputes are likely to distort trade generally, the most appropriate model is very likely to differ across regions.

The choice of Latin America does provide a good degree of variance with respect to territorial disputes across countries. For the time period examined here, ${ }^{17}$ twenty-three contiguous country-pairs have had no territorial disputes, eight country-pairs have settled their disputes, ${ }^{18}$ three are still disputing, ${ }^{19}$ and one dispute seems to have developed during the period of observation. ${ }^{20}$ Finally, because we are only interested in those cases in which there is a possibility of a territorial dispute, I focus here on contiguous country-pairs, with one exception for a case regarding islands involving noncontiguous countries. ${ }^{21}$

Time-series cross-sectional data are used for the years 1960-2000 for thirty-six country-pairs (where possible), ${ }^{22}$ and the data are analyzed using ordinary least squares and robust standard errors for clustered samples. ${ }^{23}$ Because we are analyzing time series, autocorrelation is a concern, and to address this issue I present models with and without a lagged dependent variable for easy comparison. There are strong theoretical reasons for using a fixed effects model: certainly, we are offering a 
quite spare model of bilateral trade, and have explicitly decided to set aside a number of plausible influences on bilateral trade unique to each pair. ${ }^{24}$ Country-pair dummies absorb many of the crucial aspects of geography (mountains, waterways, Amazonian jungle) that obviously influence the transactions costs of transportation, but are not picked up in our distance measure. These dummies are also likely to absorb other disturbances or dislocations of a domestic nature that affect demand and production (civil conflicts, for example). In all of the specifications below country-pair dummies are included and most are highly significant, but are not reported. ${ }^{25}$

\section{Findings}

The results of the analysis are reported in Tables $10.1 \mathrm{a}$ and $10.1 \mathrm{~b}$, and 10.2. Tables 10.1 a and $b$ differ by the inclusion of a lagged dependent variable in the latter. The two primary elements of the gravity model, distance and size of economy, work precisely as anticipated: distance reduces trade and the combined economic size of the trading partners increases it. The most important result for our purposes, however, is that the existence of a territorial dispute almost certainly puts a serious drag on bilateral trading relations. Note that the strong negative effect of disputing holds for all models in Tables 10.1a and b. The results associated with territorial disputes are always negative and twice statistically significant even when a lagged dependent variable is included (Table 10.1b).

For the period as a whole, the effect of disputing is to reduce bilateral trade by about 36 percent each year the dispute is not settled. ${ }^{26}$ For Peru and Ecuador, Model 1 estimates an average loss of about $\$ 35$ million in forgone bilateral trade for every year those two countries continued to dispute their borders. More dramatically, the model estimates that Argentina and Chile lost potentially an average of some $\$ 326$ million per year until their (multiple) territorial disputes were settled in 1995.

In order to give a clearer idea of the estimated impact of territorial disputes on trade for particular country-pairs at particular points in time, Table 10.2 shows what effect our most basic model (Model 5 Table 10.1a) would expect a territorial dispute to have had on trade during our period of observation. ${ }^{27}$ Each of the country-pairs in this table had an unresolved dispute over territory during the period under observation. Estimates of bilateral trade assuming disputes compared with no disputes are presented first. The difference between these estimates represents forgone bilateral trade attributed by this model to disputes over territory. This can be compared with actual observed trade averages for both disputed and undisputed years.

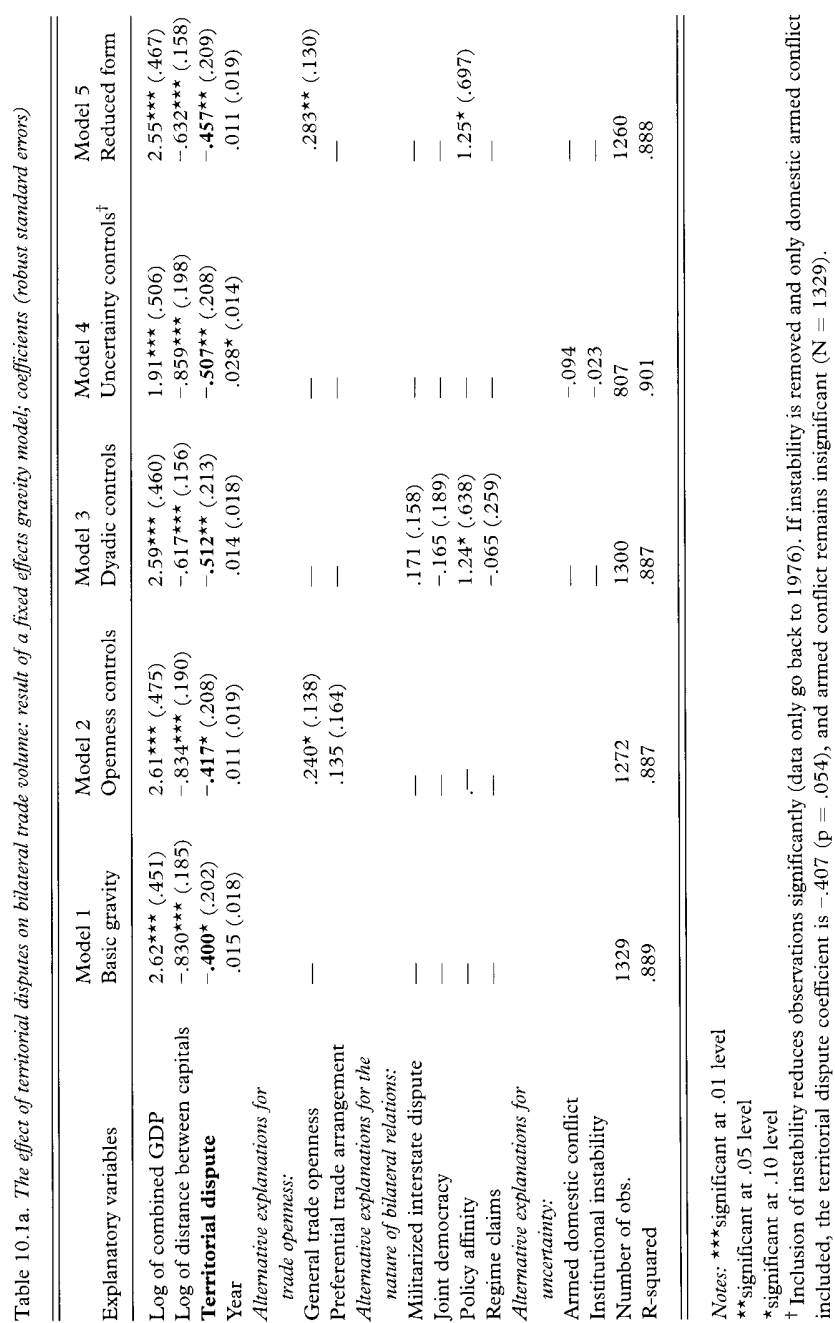


Table 10.2. Estimated effects of territorial disputes on trade, 1967-2000 (yearly averages and cumulative totals, millions of US dollars)

\begin{tabular}{|c|c|c|c|c|c|c|}
\hline & \multirow[b]{2}{*}{$\begin{array}{l}\text { Date } \\
\text { settled }\end{array}$} & \multicolumn{2}{|c|}{$\begin{array}{l}\text { Estimated } \\
\text { average yearly } \\
\text { trade }\end{array}$} & \multirow{2}{*}{$\begin{array}{l}\text { Estimated } \\
\text { cumulative impact } \\
\text { of disputing }\end{array}$} & \multicolumn{2}{|c|}{$\begin{array}{l}\text { Actual average } \\
\text { yearly trade }\end{array}$} \\
\hline & & Dispute & $\begin{array}{l}\text { No } \\
\text { e dispute }\end{array}$ & & Dispute & No dispute \\
\hline Argentina-Uruguay & 1974 & 154.51 & 242.32 & 614.67 & 33.6 & 506.50 \\
\hline El Salvador-Honduras & 1992 & 52.30 & 82.03 & 718.25 & 12,96 & 138.70 \\
\hline Argentina-Chile & 1995 & 573.54 & 899.49 & 9126.60 & 501.55 & 2730.44 \\
\hline Brazil-Uruguay & 1995 & 440.15 & 690.29 & 7003.92 & 395.51 & 1550.67 \\
\hline Guyana-Suriname & 1995 & 1.38 & 2.18 & 15.20 & 1.46 & 3.16 \\
\hline Bolivia-Chile & 1996 & 40.12 & 62.92 & 663.32 & 43.84 & 174.70 \\
\hline Ecuador-Peru & 1998 & 59.21 & 92.86 & 1043.15 & 74.94 & 182.67 \\
\hline Belize-Guatemala & unsettled & 2.29 & 3.59 & 23.40 & 4.96 & 1.10 \\
\hline Colombia-Nicaragua & unsettled & 4.88 & 7.66 & 50.04 & 8.90 & 2.75 \\
\hline Guyana-Venezuela & unsettled & 32.67 & 51.24 & 603.8 & 22.52 & $\cdots$ \\
\hline
\end{tabular}

Notes: ${ }^{\#}$ Estimates calculated based on Table 10.1a, Model 5.

The final column shows how much bilateral trade may have been reduced for each country-pair for the period as a whole. When we cumulate the effects of disputing territory between Argentina and Chile for the period under observation, for example, the total bilateral trade forgone (1967-94) is estimated to total over $\$ 9$ billion. The cumulative total for Ecuador and Peru is estimated to be over a billion dollars. To put these quantities in perspective, this is more than a third of Ecuador's and about a sixth of Peru's total overseas development assistance received during the same period. ${ }^{28}$

In most cases, country-pairs traded less on average while disputing over territory than our model predicts, and more on average than our prediction once the dispute was settled. Clearly, there is more volatility in trade than this spare model is able to detect. The model does a better job predicting the level of bilateral trade under disputes than for disputefree years, because of the greater volatility and the smaller number of data points for dispute-free years among these pairs. Actual trade figures between Colombia-Nicaragua and Belize-Guatemala go against expectations because they begin the period without disputes, but conclude under the cloud of territorial contestation. A few partners have managed to maintain high trade levels in spite of their disputes. Ecuador and Peru, for example, had levels of actual trade that were above those predicted 


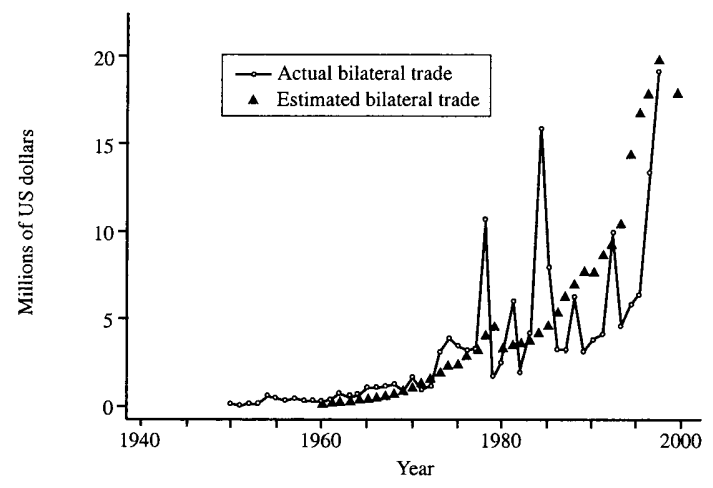

Ecuador and Peru

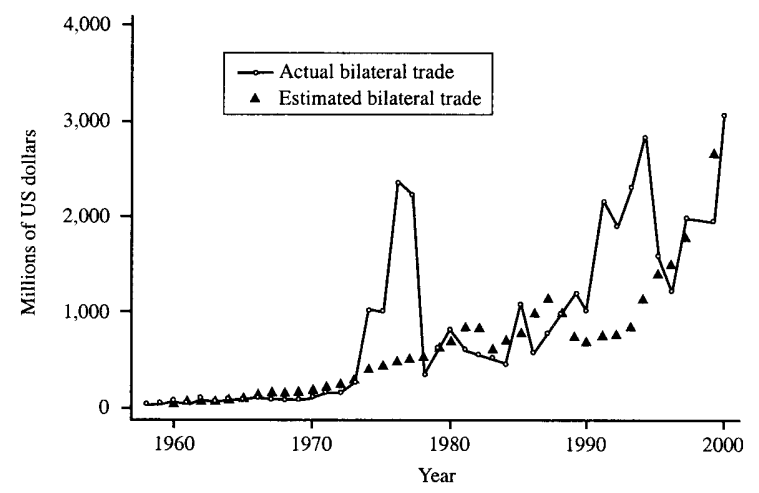

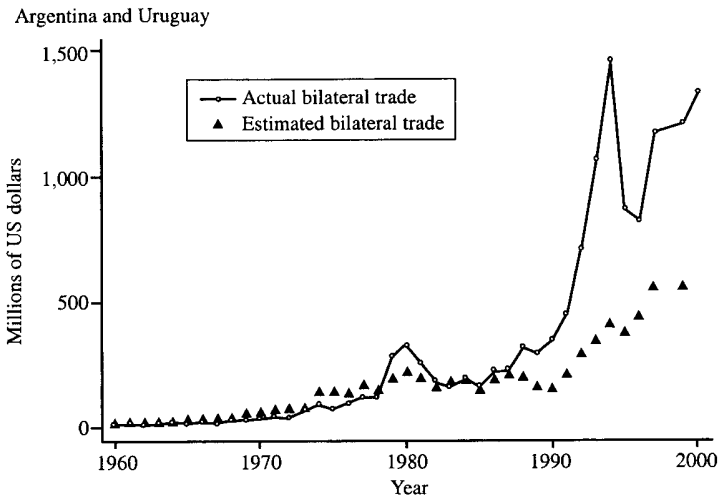

Argentina and Chile

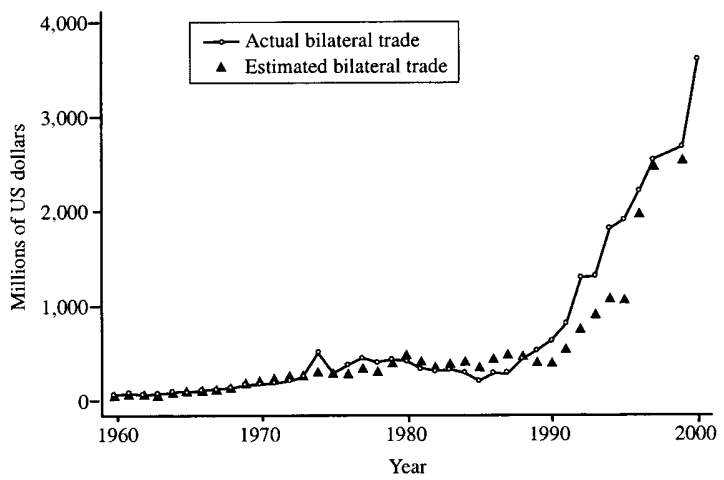

Figure 10.2. Comparison of estimated and actual trade.

under both conditions by Model 5. Overall, however, the table shows how costly it has been to bilateral economic relations - in terms of lost economic opportunities - for Latin American countries to actively contest their boundaries. 
Figure 10.2 takes a closer look at how the estimations of Model 5 square with reality. It plots actual versus predicted bilateral trade for four country-pairs based on Model 5 . In the case of Colombia and Nicaragua, the model simply could not cope with the extreme volatility in trade over the last two decades. Ecuador and Peru have had two distinct spikes in their trade that the model misses. We can see actual trade tumble in 1995, though, which is what we would expect with the deterioration that year in relations around the border. In the case of Argentina and Uruguay, we see actual trade trend upward in the $1990 \mathrm{~s}$ in what is likely the effect of Mercosur (though the effects of preferential trade agreements could not generally be detected without a lagged dependent variable; compare Model 5 across both tables). Nonetheless, trade does clearly pick up after 1974 - the year these countries' territorial claims were resolved. Finally, the model does extremely well predicting the actual trade of Argentina and Chile. The 1990s have been a boom period for bilateral economic relations between these two erstwhile territorial competitors.

It is possible that these results are simply a function of countries' developmental strategies rather than the consequence of an open diplomatic wound involving territory. Bilateral trade might be low because of a general commitment to import substitution or a policy of selfsufficiency. To account for this possibility, Models 2 and 5 include a measure of general openness. Unsurprisingly, the pairs' general export orientation is positively reflected in higher bilateral trade levels and trade increases; the latter effect is especially convincing in models containing a lagged dependent variable (Models 2 and 5). But the important observation for our purposes is that overall trade orientation does not wash out the bilateral effects of disputing; in fact in Table 10.1 a, its inclusion enhances them somewhat. Model 2, Table 10.1a, also indicates that bilateral trade levels have not been significantly affected by preferential trade arrangements: the coefficient is statistically insignificant and the impact of disputing is unaffected. Preferential trade agreements probably have contributed to bilateral trade growth however, as this variable is statistically significant when a lagged dependent variable is included (Models 2 and 5, Table 10.1b).

Nor is there much consistent evidence that the uncertainty I am attributing to unsettled borders is essentially attributable to strained underlying bilateral relations. Models 3 and 5 (Table 10.1a) show that while highly coherent positional affinities on foreign affairs within a dyad has a positive effect on trade levels, the basic finding with respect to territorial disputes is unaffected, possibly even strengthened. Controlling for regime claims had no impact on trade. Nor are regime type effects significant. It is highly unlikely that bilateral trade can be explained by processes of democratization and regime liberalization in the region. Joint democracy - a condition we might have associated with economic liberalization - is unlikely to impact bilateral trade, according to these data (Model 3 both tables). ${ }^{29}$ Indeed, in every test, joint democracy seemed to be associated with less bilateral trade, although the results are never statistically significant. The results regarding nationalist regimes were never statistically significant and since the use of this variable eliminated observations prior to 1975 I dropped this control from the analysis.

What is most fascinating about the effect of disputing territory is that it persists even when controlling for actual militarized disputes. Model 3 (both tables) Controls for the active threat, show, or use of force between the countries of a pair, and this variable has no significant impact on bilateral trade levels for these countries in this time period, though it may slow trade growth (Table $10.1 \mathrm{~b}$ ) ${ }^{30}$ Of course, the actual number of militarized disputes between Latin American countries during this time period is relatively small (see Appendix 2). Still, these results are extremely interesting for our theory of borders: beyond any damage done by the actual or imminent use of military force, the uncertainties surrounding border disputes continue to cumulate opportunity costs in terms of forgone bilateral trade. Whether or not foreign relations come to blows, trade is diminished by the exertion of contradictory sovereignty claims over the territory of a trading partner. This brings us closer to isolating the effect of territorial uncertainty itself on economic opportunity losses that cumulate over time and put a drag on the economy.

Finally, because globalization has tended to trend upward over the course of the postwar years, it would seem appropriate to control for the passage of time on bilateral trade. Surprisingly, including a variable to capture time had no significant effect on any of the variables in the analysis, nor was it significant in explaining bilateral trade (with a partial exception in Model 4, Table 10.1a). This raises our confidence that we are capturing the real effects of disputing and not simply time-related globalization trends. A check for robustness to outliers found that removing one country-pair from the sample at a time had no significant impact on the results of Model $5 .^{31}$

Do territorial disputes have a constant effect on trade over time? One possibility is that as long as governments do not act forcibly to stake their claims, economic actors become adjusted to the ambient level of uncertainty and develop economic links to the best of their ability under the tenuous circumstances. Informal norms to "agree to disagree" may develop, effectively reducing the impact of the formal dispute on trade. 


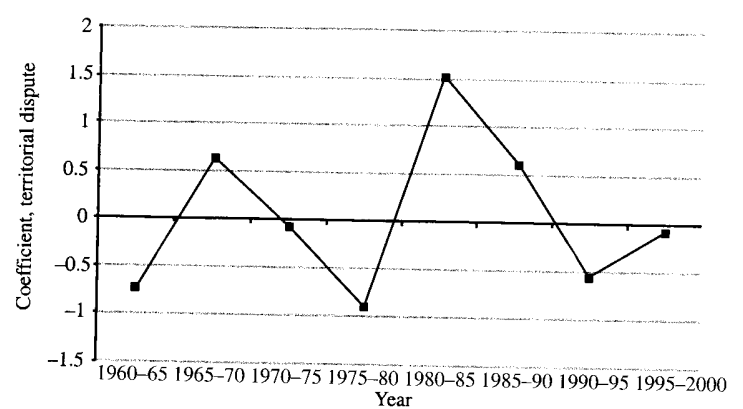

Figure 10.3. Estimated effects of territorial disputes on trade, by halfdecade.

If this is the case, we should see a trend upward in the coefficient for territorial disputes over time. Figure 10.3 displays the coefficients estimated separately for five-year periods using the specification in Model 5 (Table 10.1a). ${ }^{32}$ These five-year cross-sections produce volatile estimates (a few of which are not statistically significant) of the effects of disputing. While this period analysis returns both negative and positive coefficients, there is no clear trend in these coefficients over time. Five periods had negative coefficients (four of which were statistically significant) and three periods had positive coefficients (one of which was highly statistically significant). It is not easy to conclude that there has been a secular change in the relationship between territorial disputes and bilateral trade over the last forty years.

Finally, it is reasonable to ask whether territorial disputes have resulted in lost or merely diverted trade. If territorial disputes have simply resulted in trade diversion, then we would expect disputes to have positive effects in countries other than those whose borders are under dispute. As a first cut, we can assume that trade that might have taken place with a neighboring country, but for a territorial dispute, has been diverted to other countries in the region. Table 10.3 explores this hypothesis in two ways. First, it examines the (weighted) effect of a territorial dispute on all countries within the region with the exception of the disputing pair itself. If diversion is taking place we should expect these weighted disputes to have a positive impact on non-disputing
countries.

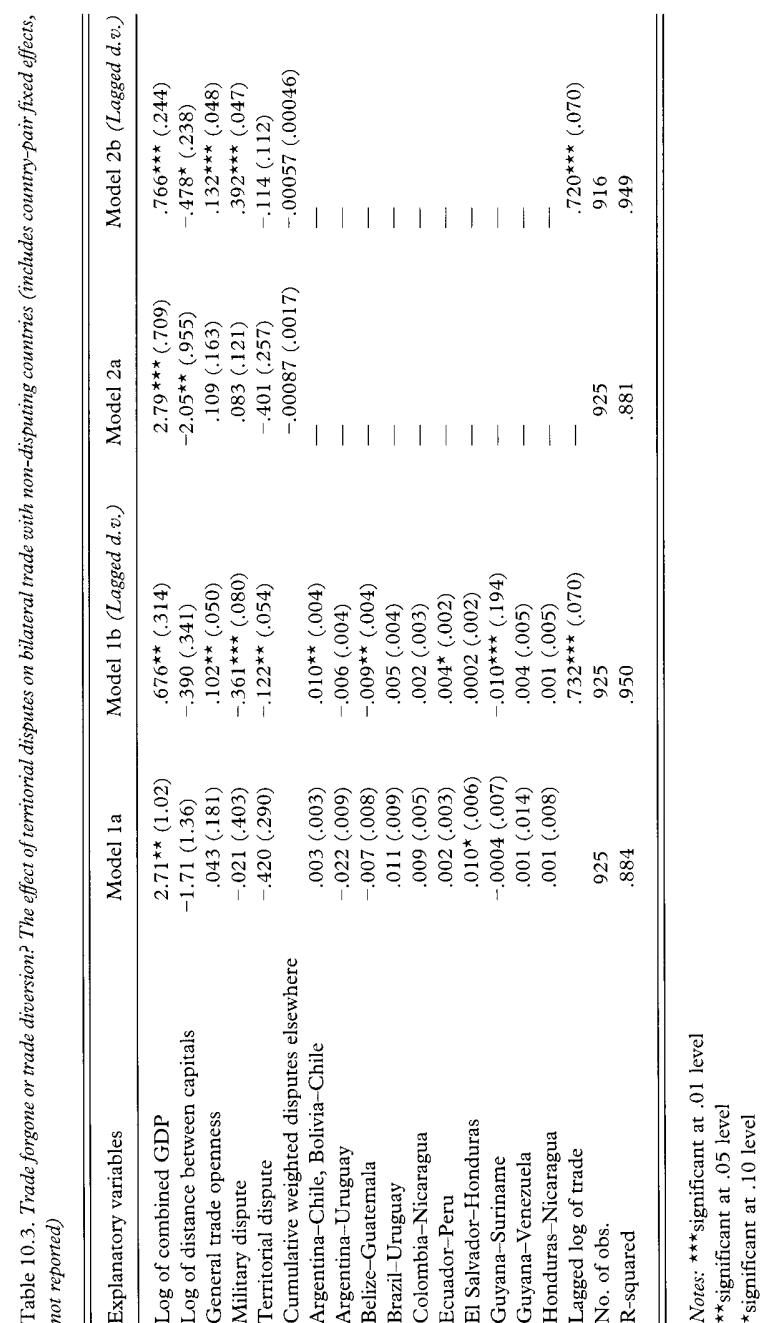


The first two columns of Table 10.3 contain little support for the diversion hypothesis. There are only two disputes that plausibly might have resulted in some trade diversion, according to these results. The first involves Chile's border resolutions with both Argentina and Bolivia. (Both of these were resolved in 1995, and they are analytically impossible to distinguish in this model. ${ }^{33}$ ) Model $1 \mathrm{~b}$, using a lagged dependent variable, suggests that trade to other countries in the region may have grown faster when these Chilean borders were under dispute than once they were resolved. The Peru-Ecuador conflict may also have resulted in some trade diversion to the rest of the region, resulting in slower trade growth elsewhere once this dispute was resolved. Nonetheless, it is difficult to find any cumulative effect of trade diversion on balance. Model 2 ( $a$ and $b$ ) shows that a cumulative measure of territorial disputes (weighted by log of GDP) had no systematic effect on countries that were not party to those disputes.

\section{Some plausible examples}

These numbers may sound abstract, but there is good evidence that governments depress trade by pressing their territorial claims. For example, while regional trade was growing, the dispute between Ecuador and Peru stunted bilateral economic relations significantly: Peru exported more to Bolivia than to Ecuador ( $\$ 166$ million compared with $\$ 147$ million between 1992 and 1994), despite the fact that Ecuador's gross domestic product is almost three times the size of Bolivia's. Moreover, Ecuador bought $\$ 684$ million worth of exports from Colombia between 1992 and 1994, and only $\$ 147$ million from Peru, even though Peru's economy is only slightly smaller than Colombia's. ${ }^{34}$ The territorial dispute between these two states likely contributed to this distorted trade relationship.

Ecuador and Peru's approach to the resolution of their conflict in 1998 demonstrates the perceived economic value of settlement. The resolution of this dispute led to a treaty on trade and navigation, ${ }^{35}$ a liberalized border regime, ${ }^{36}$ programs for binational border development projects, ${ }^{37}$ and a memorandum of understanding on tourism cooperation (Simmons 2005). The United States, as one of four guarantor states, was actively involved in facilitating the 1998 peace accord between Peru and Ecuador and remains committed to its implementation, having pledged $\$ 40$ million to the Peru-Ecuador border integration project. ${ }^{38}$ While not on track to meet the $\$ 6$ billion bilateral trade goal announced by the two countries' presidents in $1998,{ }^{39}$ bilateral trade between these two countries has soared from $\$ 119$ million in 1995 (the year of active hostilities at the border) to $\$ 232$ million in 2000 . $^{40}$

Meanwhile, those governments that continue to dispute their borders continue to lose out on economic opportunities. In Central America, the Common Market arrangement collapsed when Honduras and El Salvador went to war over territorial issues in 1969. Integration efforts in the region weakened due to the renewed severity in the $1990 \mathrm{~s}$ of Central American territorial disputes. Both Guyana and Belize suffer from deterred investment in their countries, largely owing to the uncertainty surrounding the territorial claims of Venezuela and Guatemala, respectively. In 2000 for example, Guyana suffered a direct economic loss when Beal Aerospace Technologies canceled its planned development project because of Venezuelan threats on Guyana were the project to go forward (Serbin 2001). ${ }^{41}$ Investment in Guyana further suffered that year when Venezuela commenced oil exploration in the controversial offshore exclusive economic zone, in retaliation for Guyana's granting of licenses to Exxon and Century for oil exploration in the disputed Essequibo region. ${ }^{42}$ Venezuela's effort to punish Guyana by excluding it from preferential access to Venezuelan oil has only been avoided by the intercession of CARICOM members. ${ }^{43}$ The ongoing dispute between Nicaragua and Colombia provides another example of institutional uncertainty for transnational business relations. In December 1999, according to the United States Trade Representative, Nicaragua imposed a punitive 35 percent tariff on all goods from Honduras and Colombia as a retaliatory measure for Honduras' signing of a maritime border delineation agreement with Colombia, which Nicaragua claims infringes on its territory. ${ }^{44}$ These are hardly the conditions under which traders and investors feel secure in developing external economic relations.

\section{Conclusions}

Border disputes have led to serious economic opportunity costs, even in cases where trade partners have never exchanged an explicit military threat. Notwithstanding a few excruciating exceptions, far from living in a "borderless" world, we live for the most part in a well-bordered world; one in which humans have accepted the boundaries of jurisdiction and sovereignty and have gone on to trade, invest, travel, and communicate across well-established political jurisdictions. The central claim of this chapter is that we are able to do these things precisely where governments have accepted as settled the first-order question of who is formally 
sovereign over what geographical space. The most permeable political boundaries in the world tend to be those that are taken for granted by both of the bordering political authorities, as well as by other governments in the region. The Canadian-US border comes to mind, as do borders between the countries of Western Europe. The razor wire separating Israeli and Palestinian settlements provides a tragic contrary example. David Newman's contribution to this volume reminds us that in many cases territorial attachments remain profound and, effectively, non-negotiable.

Nonetheless, political boundaries are human institutions. Just as people who are in love in most modern cultures tend to get married (which provides them with a set of clearly defined rights that love outside of marriage does not), countries who want to benefit fully from cordial relations settle their territorial disputes and go on to enjoy joint gains from the set of recognized rights that exclusive jurisdiction affords. I have framed these joint gains in this research in terms of lost trading opportunities. But they include as well the economic joint gains of investment, travel, tourism, as well as a host of positive externalities associated with friendly bilateral diplomatic relations with a neighbor. Of course, once territorial disputes turn violent the human suffering and the costs associated with the use of military force mount and potentially create humanitarian crises that far outweigh the economic considerations analyzed here. But $I$ have been at pains to demonstrate that even non-military disputes over territory - by virtue of the uncertainty and ill will they sow - entail costs that have rarely been explicitly considered.

Nor are the results I have attributed to territorial disputes likely to be a mere reflection of uncooperative bilateral relations that have led both to disputing and to underdeveloped trade. One advantage of the fixed country-pair effects model is its ability to control for constant features of the dyad that otherwise might lead to spurious conclusions about the border settlement-trade link discussed here. In addition, several models controlled for conditions that could reflect changes in the general cordiality of the bilateral relationship over time (the rise and fall of nationalist governments, conditions of joint democracy, challenges to the legitimacy of governance, changes in the compatibility of outlook with respect to foreign affairs generally). These controls ameliorate (but of course do not eliminate) the possibility of spurious correlation.

A simple gravity model of bilateral trade suggests that the costs associated with border disputes are likely to be significant. Ecuador and Peru likely missed out on hundreds of millions of dollars of bilateral trade owing to their long-running controversy over a large tract of undeveloped Amazonian jungle. The same can be said for Argentina and Chile with their multiple disputes over the Beagle Channel, Patagonia, and the Ice Fields. A fraction of these flows may have been diverted to other regional trade partners; nonetheless, case studies suggest that in negotiating a settlement leaders in these countries were indeed cognizant of these costs, and viewed them as one reason for hastening agreement over the legitimate location of the international border (Simmons 1999). Jorge Dominguez has argued that in Latin America, the greater the developmental objective of the government, the more likely it will engage in a grand strategy that ends in the resolution of territorial disputes (Dominguez 2001). Colombia and Nicaragua are two countries that would do well to pursue such a strategy, as they have lost a total estimated $\$ 50$ million in bilateral trade since their dispute over a cluster of Caribbean islands erupted in 1980. Perhaps this is one reason Nicaragua has recently decided to initiate settlement proceedings at the International Court of Justice.

The theoretical implications of these findings are profound. Realist lenses have provided the focus for the mainstream study of territorial disputes and their resolution in the field of international relations. Territory is viewed in zero-sum terms, and theories about peace and conflict, disputation and resolution have revolved around traditional problems of dividing the territory, its strategic importance, its resource endowment, and other power considerations. Very few studies have considered the possibility of joint gains, and none have considered joint gains beyond joint natural resource exploitation.

Institutionalist theory provides a natural way to think about political boundaries. Governments create them and accept them as legitimate in order to overcome uncertainty, high transactions costs, and other negative externalities that flow from contentious territorial claims. Such a paradigm shift would lead us to investigate the extent to which growing opportunity costs (alongside more traditional considerations) provide an impetus for governments to settle their disputes, even turning at times, contrary to realist expectations, to authoritative third parties to render legally binding rulings (Simmons 2002). As regional trade intensifies, governments should be increasingly willing to settle their territorial disputes so as not to get left behind as the regional integration train pulls away from the station. Theories of the settlement of territorial claims have much to gain from the institutional literature on cooperation generally. 


\section{Appendix 1: Data}

\section{Dependent Variable}

Bilateral trade. The logged sum of imports into Country A originating from Country B plus the sum of imports into Country B originating from Country A, in millions of US dollars. Source: International Monetary Fund, Direction of Trade Statistics, various years.

\section{Explanatory Variables}

Combined GDP. The log of the sum of gross domestic product of Country A and Country B, in millions of US dollars. Source: World Bank, World Development Indicators, at http:devdata. worldbank.org.ezp2.harvard.edu./dataonline/.

Distance between capitals. The log of the distance in kilometers between capital cities. Because it is not Brazil's major city, Brasilia was replaced with Rio de Janeiro. Source: http://www. indo.com/distance/index.html.

Territorial dispute. Whether (1) or not (0) incompatible claims over territory are made by government officials. For a discussion of the criteria see text and footnote 12. Source: Huth 1996. Updates to these cases were made using newspaper reports and various country-specific sources.

Military dispute. Whether (1) or not (0) either government of the disputing pair engaged in the threat or use of force against the other member of the pair. Source: Militarized interstate disputes (MIDs) data set.

Year. Calendar year.

foint democracy. Whether ( 1 ) or not (0) both countries in the pair score above a 5 on the polity score. Range: 10 (highly democratic) to -10 (completely non-democratic). Source: Polity IV data set.

General trade openness. Log of the product of Country A's and Country B's total imports and exports as a proportion of each country's GDP. Source: World Bank, World Development Indicators.

PTA membership. Coded 1 if both countries in the pair are members of the same PTA, 0 otherwise. Sources: WTO website (http: www. wto.org) and http://www.sice.oas.org.

Affinity index. Index of the cohesion for each country-pair year on UN General Assembly votes. The index ranges from a low of 0 to a high of 1 . Source: Erik Gartzke and Dong-Joon Jo, "The Affinity of Nations Index, 1946-1996," available at http://www.columbia.edu/ eg589/datasets.htm. The average from the preceding year was used to bring the data up to 2000 .

Nationalist government. Coded 1 if the party of the chief executive was nationalist, 0 otherwise. Source: World Bank.

Regime claims. Case is coded 1 if there is at least one regime claim in a given year, 0 otherwise. A regime-based claim involves explicit contention between two or more states over a regime's control of the governing apparatus of one of the states. Essentially, one government issues a verbal challenge to the other state's regime, calling for its removal. Official representatives of the state's government must support the regime claim - an unambiguous statement calling for the removal of another regime. See Tures 2000. Source: Obtained from Paul Hensel's website: http://garnet.acns.fsu.edu/ phensel/icowdata. html\#territory. Accessed 10 December 2003. 

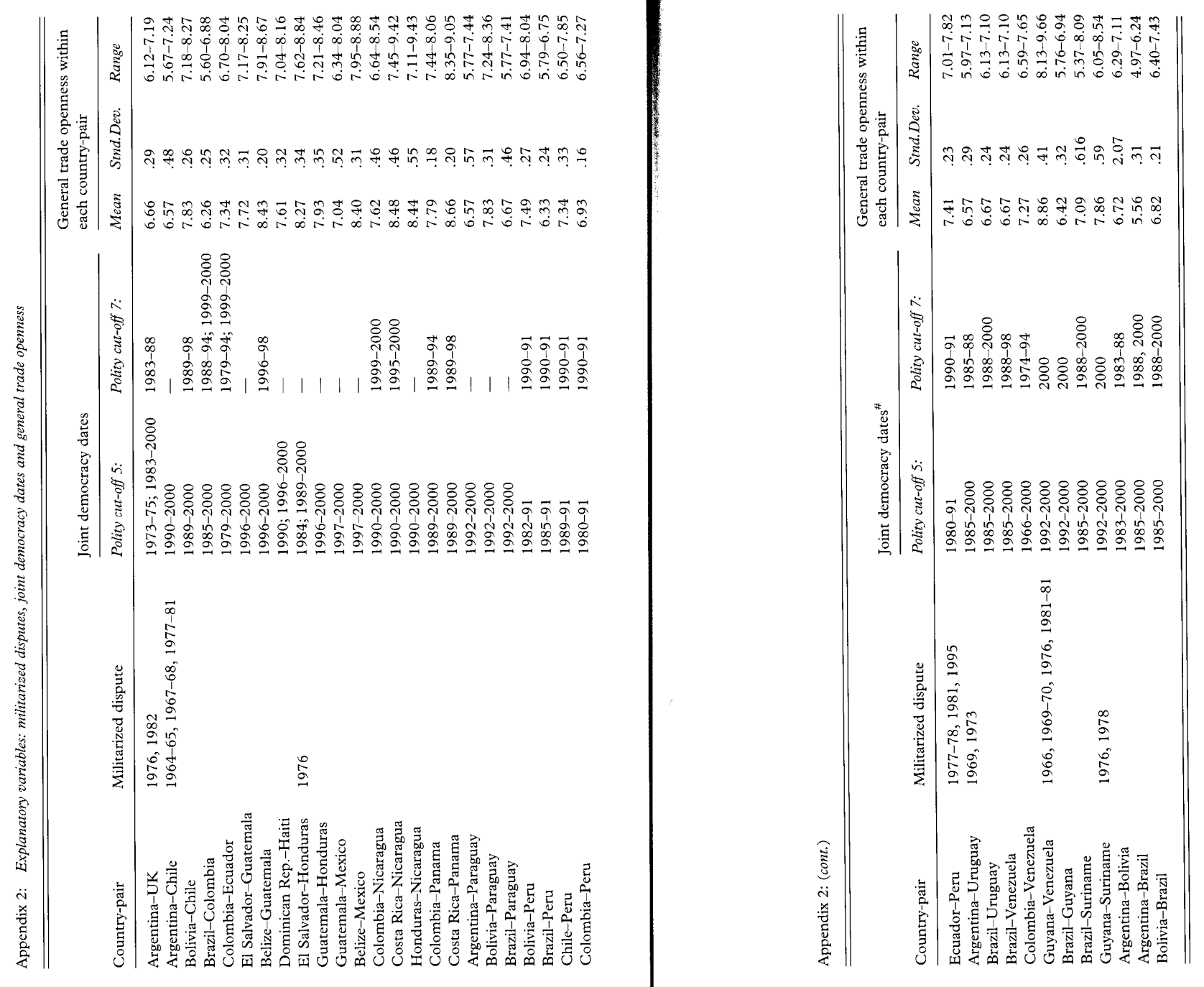
NOTES

1 These issues were, to my knowledge, first explored empirically by Albert Hahn in "Borders, Conflict, and Money: The Effect of Territorial Disputes on Bilateral Trade from 1950 to 1990." MA thesis, UC Berkeley Department of Political Science, 2000.

2 Morgenthau was also willing to recognize the reduced importance of territory in the nuclear age (Biersteker 2002).

3 But see Barbieri and Levy 1999; Barbieri and Levy 2001.

4 Brian Pollins, for example, found that "importers (regardless of the level of analysis we choose) take account not only of price and quality of goods and services but of the place of origin of these products and the political relationship between the importing and the exporting nation" (Pollins 1989, 738). Pollins also notes that exporters are subject to the same considerations.

5 But see Carlile 1994

6 Yarbrough and Yarbrough suggest that demands for sovereign control over territorial resources should be related to transactions costs. They argue that economic agents are likely to want to change international boundaries in order to reduce transactions costs by bringing resources under a single governance structure (Yarbrough and Yarbrough 1994).

7 This point has long been recognized by liberals such as Norman Angel (1911) who, on the eve of World War I, was highly skeptical of the idea that sovereign territorial acquisition would provide a basis for prosperity and influence (Angell 1911).

8 This point is made with respect to South Asia by Gupta (1997).

9 The effect of a territorial dispute on a country's total trade is not explicitly tested here. There is some possibility that disputes divert a portion of potential bilateral trade to third countries. Such diversion is not likely to absorb all of the potential trade between disputants, and in any case is not likely to be as efficient as trade between contiguous neighbors.

10 Certainly, other kinds of international disputes may also affect bilateral trade Political or ideological disputes, such as that between the United States and Cuba, are also candidates for reducing trade. The effect of foreign policy posture on trade has been analyzed by Pollins (1989). The purpose here is to focus explicitly on territorial disputes as a way to motivate a theoretical re-orientation of international boundaries.

11 When trade is zero, the value zero was kept instead of allowing it to fall out after the $\log$ function.

12 Huth $(1996,23)$ defines the end of a dispute as:

a The occupation and assumption of control over disputed territory by the challenger being formally recognized by the target in a treaty, an international agreement, or in an official statement by the political leadership of the target.

$\mathrm{b}$ The signing of a bilateral agreement with a target or an official statement by the challenger in which its territorial claims are either renounced or are satisfied with a compromise settlement.

c The challenger agreeing to abide by a ruling issued by the ICJ [International Court of Justice] or an international arbitration panel.

13 On the value of formal arrangements (usually treaties) for signaling an intention to comply, see Abbott and Snidal 2000; Lipson 1991

14 There is a mild positive correlation between territorial disputes and military disputes of .258 in this data set.

15 Erik Gartzke and Dong-Joon Jo, "The Affinity of Nations Index, 19461996." Available at http://www.columbia.edu/ eg589/datasets.htm.

16 Tests including nationalist governments drop all observations prior to 1975

17 Reliable GDP data - essential for the gravity model - are difficult to assemble in a consistent time series for some of these countries prior to the early $1960 \mathrm{~s}$.

18 Honduras and Nicaragua (1960), El Salvador and Honduras (1992), Argentina and Uruguay (1973), Guyana and Suriname (1994), Brazil and Uruguay (1994), Argentina and Chile (1995), Bolivia and Chile (1995), and Ecuador and Peru (1998).

19 Belize and Guatemala, Guyana and Venezuela, and Colombia and Nicaragua.

20 The dispute between Nicaragua and Colombia seems to have opened in 1980 with Nicaragua's assertion of a claim to the islands of Providencia, San Andres, and Santa Catalina, which are claimed also by Colombia.

21 The noncontiguous case is that of Colombia and Nicaragua. The use of contiguous pairs necessitates the use of distance between capitals as our measure of distance. In Brazil's case, Rio de Janeiro is used instead of Brasilia.

22 The following countries do not enter the data set until the date of their independence: Guyana (1966), Suriname (1975), and Belize (1981).

23 Robust to deviations from ordinary assumptions of independent, identically distributed errors. The purpose is to adjust standard errors taking into account non-independent observations within country-pairs.

24 For a discussion of the use of fixed effects, see Green et al. 2001

25 Full results including coefficients on country-pair dummies are available from the author upon request.

26 Using the coefficient for logged bilateral trade in Model 5, Table 10.1a, this is calculated as $1-e^{-45}$.

27 I choose to present the substantive results using Model 5, Table 10.1a because it returns a mid-range estimate of the impact of trade disputes.

28 Ecuador received about $\$ 2.83$ billion and Peru about $\$ 6.1$ billion in official overseas development assistance during the period of their territorial dispute. Figures are from the World Bank's World Development Indicators CD-ROM.

29 This result is robust to varying specifications of joint democracy. While the above results relate to a mutual cut-off point of 5 on the combined democracyautocracy index (ranging from -10 to 10 ), a similar coefficient results from a mutual cut-off at $7(-.123$, with s.e. of .248$)$.

30 Moreover, when military disputes are inserted into Model 1 and territorial disputes are removed, military disputes alone have no apparent effect on bilateral trade (coefficient .072, standard error .157). This raises our confidence further that the institutional uncertainty of a border conflict rather than military conflict per se puts a drag on trade.

31 Territorial disputes remained highly statistically significant in each case. The estimated coefficient ranged from a high of -.650 when Bolivia and 
Chile were removed, to a high of -.412 when Guyana and Suriname were removed.

32 Using the coefficients from Model 2 produces substantially the same results.

33 As was Argentina's dispute with the United Kingdom over the Falkland Islands.

34 All figures are from the Inter-American Development Bank.

35 The two presidents signed a Trade and Navigation Treaty that spelled out the rights and responsibilities of both countries with respect to Ecuador's guaranteed (but nonsovereign) access to Amazonian shipping routes. Thi treaty begins by re-emphasizing all of Ecuador's rights as enumerated in Article 4 of the Protocol of Rio de Janiero (1942). Article 2 of the Trade and Navigation Treaty gives Ecuador explicit access to an (unnamed) river through Peruvian territory that will permit them to connect their shipping directly with the Amazon. The agreement also gives Ecuador the right to enjoy free land transit by the public access roads, and the use on a nondiscriminatory basis of dock services available as specified points on the river Article 2 states that "These rights will be exercised freely, without cost, continuously and forever." Several articles in the Treaty provide for national treatment of Ecuadoran shipping and cargoes. In order to facilitate storage and transshipment, Article 22 provides for the creation for fifty years (renewable) of two "trade navigation centers" financed, constructed, operated, and administered by a private Ecuadoran firm, appointed by the Ecuadoran government, subject to Peruvian regulations. Article 24 provides that goods shipped through Peruvian territory (though not goods destined for Peru) are to pass duty free, while Article 35 reciprocally grants Most Favored Nation status. Finally, the Trade and Navigation Treaty contains provisions for the resolution of future disputes. It establishes an "Ecuadorian-Peruvian Trade and Navigation Commission," which is to be in charge of addressing controversies arising from the Treaty (Article 37). If the Commission canno resolve any controversies arising from the agreement within sixty days, it is to be referred to the Ministries of Foreign Affairs of both countries, to be handled through diplomatic means (Article 38). For a summary and discussion of the Treaty, see http://www.asil.org/ilib/ilib0111.htm 02 .

36 A new border regime was agreed in order to enhance commercial and tourist traffic, through the opening of new and more liberal border crossings. Presidential Act of Brasilia (1998), Arts. 12-15.

37 Title V of the Comprehensive Agreement signed in 1998 envisaged a ten-year plan, to be developed by a Bilateral Executive Board and an International Advisory Committee, to develop programs to encourage social, economic, and environmental infrastructure, as well as to promote private sector investment in these areas in the border regions (Arts. 18-20). A highway linking Mendez, Yaupi, and Borja - to be completed by 2005 - was for example considered a top priority (Art. 21). These projects are to be financed by direct contributions of the governments of Peru and Ecuador, a Bilateral Fund for Peace and Development, monies raised by an International PeruEcuador Financial Consulting Group, a Bilateral Group for the Promotion of Investment, "and others" (Art. 22). The agreement envisages support for the larger projects from the Inter-American Development Bank, the Andean
Development Corporation, specialized agencies within the UN system, and "governments of friendly countries" (Art. 28).

38 CIA World Factbook 2004, US Dept. of State Country Background Notes.

39 Robert Taylor, "Peru/Ecuador: A Peaceful Year." World Press Review, January 2000,18 . See also Susana Madera, "Ecuador-Peru Peace Could Boost Trade to Six Billion Dollars Next Decade." EFE News Services, 25 October 1999.

40 International Monetary Fund, Direction of Trade Statistics.

41 Beal also announced that it was folding in that same year.

42 Stabroek News (Guyana), 6 August 2000. http://www.landofsixpeoples.com/ gynewsjs.htm

43 Guyana has been able to benefit from Caracas Energy Cooperation Agreement (CECA) following agitation by its CARICOM partners and the For eign Ministry. Guyana was initially excluded by Venezuela when it made the offer to the Caribbean Community. "Guyana/Venezuela Activate Energy Accord," Stabroek News, 30 November 2002.

44 See http://www.ustr.gov/html/2001 nicaragu.pdf. 